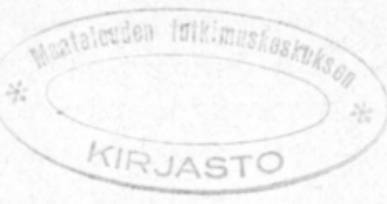

\title{
In vitro evaluation of protein digestibility in the abomasum and small intestine of ruminants
}

\author{
JOUKO SETÄLÄ, HANNA VÄÄTÄINEN ${ }^{1}$ and TERTTU ETTALA \\ Valio Finnish Co-operative Dairies' Association, \\ Research and Development Department, \\ P.O. Box 176, SF-00181 Helsinki, Finland
}

\begin{abstract}
The investigation included studies with microbial protein, 0,5 \% formaldehyde $(\mathrm{HCHO})$ treated protein in soybean meal, and ruminally undegradable feed proteins in cotton seed and sunflower seed cakes. Microbial mass was separeted with centrifugations from the rumen contents of roughage-fed sheep. Undegradable feed proteins were prepared with the nylon bag technique.

The proteins were digested in solutions of pepsin- $\mathrm{HCl}$ and trypsin-chymotrypsin. The average digestibility for microbial protein was $80.7 \%$. The corresponding values for the undegradable proteins in cottonseed cake and sunflower seed cake were $83.7 \%$ and $82.7 \%$. In the incubation with pepsin- $\mathrm{HCl}, \mathrm{pH}$ in the solution affected significantly $(\mathrm{P}<0.001)$ the digestibility of $\mathrm{HCHO}$-treated protein in soybean meal. The average digestibilities at $\mathrm{pH}$ $1.5-2.0$, $\mathrm{pH} 2.5-3.0$, and $\mathrm{pH} 3.1-4.0$ were $97.2,76.0$, and $71.0 \%$, respectively.
\end{abstract}

\section{Introduction}

In vitro tests of protein digestibility have mainly been used for non-ruminants. In the studies for ruminants KowalczyK et al. (1977, 1978 a, b) used abomasal fluid from a fistulated animal and they also evaluated protein digestibilities with rats. Multi-enzyme tests were used when the digestibilities of ruminally undegradable feed proteins (in sacco) were analyzed. In nylon bag studies in vitro methods would most obviously be relevant, because the digestibility of undegradable protein has to be estimated from a very small sample. The digestibility of microbial protein separated from the rumen contents could also be determined (e.g. BERGEN et al. 1967).

The aim of the present study was to investigate possibilities to use in digestibility analyses a method which included protein treatments with pepsin- $\mathrm{HCl}$ and trypsin-chymotrypsin. This method was chosen, because it

Department of Animal Husbandry, University of Helsinki, SF-00710 Helsinki, Finland

Present address: Agricultural Research Center,

Department of Animal Husbandry, SF-31600 Jokioinen, Finland 
was reported e.g. by MozersKy and PANETTIERI (1983) that the methods based on a pH drop in the incubations (e.g. Hsu et al. 1977), would not be applicable to proteins of which the in vivo digestibility is not known. The present study included investigations mainly with the protein in microbial mass, which was separated from the rumen contents of sheep. The digestibility of ruminally undegradable protein in sunflower seed cake, cottonseed cake, and formaldehyde treated protein $(0.5 \%$ treatment level $)$ in soybean meal was also studied.

\section{Materials and methods}

\section{In vitro technique}

The technique was modified using procedures described in the literature, mainly those by Akeson and Stahman (1964), and ANON (1970). The procedure was divided into two phases, incubations with pepsin$\mathrm{HCl}$ and with trypsine and chymotrypsine. In the first phase samples of $500 \mathrm{mg}$ were incubated at $+39^{\circ} \mathrm{C}$ in pepsin- $\mathrm{HCl}$ solution for 16 hours. Pepsin (Merck 7190, 1 : 10000, 2000 FIP-U/g) concentration in the solution of $0.05 \mathrm{~N} \mathrm{HCl}$ was $0.1 \%$. The ratio of the solution to the sample protein was 0.7 $\mathrm{ml} / \mathrm{mg}$ protein. The amount of pepsin- $\mathrm{HCl}$ was hence changed according to the amount of protein in the sample, because Van BRUCHEM and Van't KLOOSTER (1980) suggested that proteins stimulated abomasal secretions of acid in vitro. Incubations were made in glass tubes (volume $100 \mathrm{ml}$ ) with rounded bottoms and the tubes were carefully shaken at the beginning of the incubations. The $\mathrm{pH}$ in the incubations was always kept under $\mathrm{pH}$ 2.0.

In the second phase contents of the tubes were centrifuged at the speed of $400 \mathrm{~g}$ for 10 min. Supernatant in the tube was carefully discarded and the sediment was neutralized ( $\mathrm{pH}$ 7.0) using washings with phosphate buffer $(\mathrm{pH} \mathrm{7.0)}$. The contents of the tubes were centrifuged as described above and the sediment was taken for further analyses.

Solutions of bovine chymotrypsine (Merck 2307, $45 \mathrm{U} / \mathrm{mg}$ ) and bovine trypsine (Merck $24579,3.5 \mathrm{U} / \mathrm{mg}$ ) were prepared in phosphate buffer ( $\mathrm{pH} 7.0$ ) using $50 \mathrm{mg}$ of chymotrypsine, or $5 \mathrm{mg}$ of trypsine for $50 \mathrm{ml}$ of the buffer.

The solutions of trypsine and chymotrypsine were added into the tubes so that the amounts were $10 \mathrm{ml}$ and $1 \mathrm{ml}$, respectively. In addition, $9 \mathrm{ml}$ of the buffer was transferred into the tubes.

The incubations in the second phase were made (at pH 7) at $+39^{\circ} \mathrm{C}$ for 24 hours. After this the samples were centrifuged as described earlier. The supernatants in the tubes were carefully discarded and the sediments (undigestible protein of the sample) were transferred for the analysis of protein $\mathrm{N}$.

\section{Analysis of protein $\mathrm{N}$ in the samples}

The sample was transferred into the Kjeldahl bottle and incubated in $80 \mathrm{ml}$ of distilled water, at $+70^{\circ} \mathrm{C}$ for 1.5 hours. The contents of the bottles were carefully stirred 4-5 times during the incubation.

After this incubation $1.5 \mathrm{ml}$ of $\mathrm{Al}_{2}\left(\mathrm{SO}_{4}\right)_{3} \mathrm{~K}_{2} \mathrm{SO}_{4} \cdot 12 \mathrm{H}_{2} \mathrm{O}, 15 \mathrm{ml}$ of the solution of copper sulphate $\left(156.4 \mathrm{~g} \mathrm{CuSO}_{4} \cdot 5 \mathrm{H}_{2} \mathrm{O}\right.$ in $1000 \mathrm{ml}$ of distilled water), and $15 \mathrm{ml}$ of $2.5 \% \mathrm{NaOH}$ were added into the bottles. When the contents of the bottles were cool and clear they were squeezed through an $\mathrm{N}$-free filter paper, and the sample on the filter paper was washed with $750 \mathrm{ml}$ of warm, distilled water. The sample and the paper were carried to $\mathrm{N}$ determination which was made using the Kjeldahl method but excluding $\mathrm{CuSO}_{4}$ as a catalyst. Blank tests including filter paper and reagents were used in all determinations. The method described is based on the procedure used at the Department of Animal Husbandry, University of Helsinki. 
Separation of microbial mass from the rumen contents

Microbial mass was separated from the rumen contents of fistulated sheep in the hay or hay and grass silage (65:35 on DM basis) diets. Rumen contents were collected from different parts of the rumen, squeezed through a cheese cloth, and the filtrate was centrifuged at $400 \mathrm{~g}$ for $5 \mathrm{~min}$. The sediment was discarded and the filtrate was further centrifuged over $30000 \mathrm{~g}$ at $+2^{\circ} \mathrm{C}$ for 20 min. The sediment was carefully separated and stored frozen for the analyses.

\section{Samples of feed proteins}

The samples of the formaldehyde treated protein in soybean meal, and ruminally undegradable (in sacco) proteins in sunflower seed cake, and cotton seed cake were prepared by Dr. Torben Hvelplund, National Institute of Animal Science, Denmark (see Hvelplund 1983).

\section{Results and discussion}

\section{Studies with microbial protein}

Composition of the microbial mass

Fresh, separated microbial mass was used in incubations. Samples were not dried before incubation, because WALLACE (1983) among others suggested that for instance freeze drying might affect digestibility. Crude protein $(\mathrm{N} \times 6.25)$ content in the random-sampled $(n=7)$ mass was $37.1 \pm 1.0 \%$ in fresh weight. The proportion of protein $\mathrm{N}$ in total $\mathrm{N}$ was $86.7 \pm 0.7 \%(\mathrm{n}=7)$.

Effect of $\mathrm{HCl}$ and the enzymes on digestibility

According to our results $\mathrm{HCl}$ alone gave a poor digestibility value for microbial protein (Table 1). Moreover, the combination of $\mathrm{HCl}$ and pepsin was not sufficient eith- er, and it could be suggested that one of the enzymes in the pancreatic fluid is needed for a proper protein digestion. However, pepsin- $\mathrm{HCl}$ might have more importance in the digestion of the protein of plant origin when the sample is less digestible owing to the fibrous structure etc. On the other hand, ROJAHN and WAGNER (1961) observed the difference of $9 \%$-units only in the digestibility of barley protein when the estimation was made either with pepsin$\mathrm{HCl}$ (lower values) or with pepsin- $\mathrm{HCl}$ and pancreatin.

Those incubations in which a stronger $\mathrm{HCl}$ was used, tended to give higher digestibilities for microbial protein. KonTE (1979) wondered whether results of this kind could be caused by a better digestibility of nucleic acids in microbial cells. However, our results emphasized the importance of the enzymes of the pancreatin in the digestion of microbial protein.

\section{Digestibility of microbial protein}

When the digestibility of microbial protein was determined with the pepsin- $\mathrm{HCl}$ and trypsin-chymotrypsin, the mean of the digestibility was $80.7 \%$ (see Table 1). This value is the same average value which could be calculated (e.g. $80.4 \%$ ) from the papers of TAs et al. (1977), HAGEMEISTER et

Table 1. The effect of different factors on the digestibility- $\%$ of microbial protein in vitro.

\begin{tabular}{|c|c|c|c|}
\hline & \multicolumn{2}{|c|}{ Digestibility- $\%$} & \multirow[b]{2}{*}{$\mathrm{N}$} \\
\hline & $\bar{x}$ & SEM & \\
\hline $0.05 \mathrm{~N} \mathrm{HCl}$ & 20.5 & 0.9 & 2 \\
\hline $0.05 \mathrm{~N} \mathrm{HCl}+$ pepsin & 69.2 & 1.0 & 2 \\
\hline $\begin{array}{l}0.05 \mathrm{~N} \mathrm{HCl}+\text { pepsin, } \\
\text { chymotrypsin }\end{array}$ & 86.1 & 0.3 & 2 \\
\hline Trypsin + chymotrypsin & 81.2 & 1.4 & 4 \\
\hline $\begin{array}{l}0.05 \mathrm{~N} \mathrm{HCl}+\text { pepsin, } \\
\text { chymotrypsin and trypsin }\end{array}$ & 80.7 & 0.8 & 14 \\
\hline $\begin{array}{l}0.14 \mathrm{~N} \mathrm{HCl}+\text { pepsin, } \\
\text { chymotrypsin and trypsin }\end{array}$ & 86.5 & 1.1 & 4 \\
\hline
\end{tabular}

$\mathrm{N}=$ number of incubations 
al. (1980), Storm \& Ørskov (1982), Hvelp. LUND (1983), Storm et al. (1983), and W LACE (1983). In some of the incubations digestibility of microbial protein differed quite clearly from the mean value. This type of variation was also found by BUCHMANN (1979) between in vitro incubations. In the present study the coefficient of the variation $(\mathrm{CV}-\%)$ of the results between the incubations was $3.7 \%$, being higher than reported by $\mathrm{BuCH}$ MANN (1979).

In the experiments reviewed from the literature there was also a great variation in the results between different investigations. This can be partly explained by the different experimental techniques. However, BERGEN et al. (1967) and W ALLACE (1983) showed great differences in protein digestibility between bacterial strains and therefore part of the differences between different studies and incubations (present study) might be explained by the different composition of the bacterial mass digested. Ecpecially the increase in the proportions of Gram + (WALLACE 1983) or cellulolytic bacteria (BERGEN et al. 1967) in microbial mass can decrease digestibility of microbial protein. In our technique, occasional difficulties in squeezing the small sample in different phases of the work contributed also most evidently to the variation of the results.

\section{Studies with microbial protein and feed protein}

\section{Effect of $\mathrm{pH}$ and incubation period}

During the incubations the $\mathrm{pH}$ in the contents of the tubes was carefully followed. The corresponding values in pepsin- $\mathrm{HCl}$ incubations and in trypsin-chymotrypsin incubations were $\mathrm{pH} \quad 1.6 \pm 0.02$ and $\mathrm{pH}$ $6.9 \pm 0.01$.

It is doubtful, however, whether $\mathrm{pH}$ in the contents of the abomasum and small intestine remains so stable in vivo. In the experiment with goats von ENGELHARDT and HaUF. FE (1975) found $\mathrm{pH} 2.3 \pm 0.3$ in the aboma-

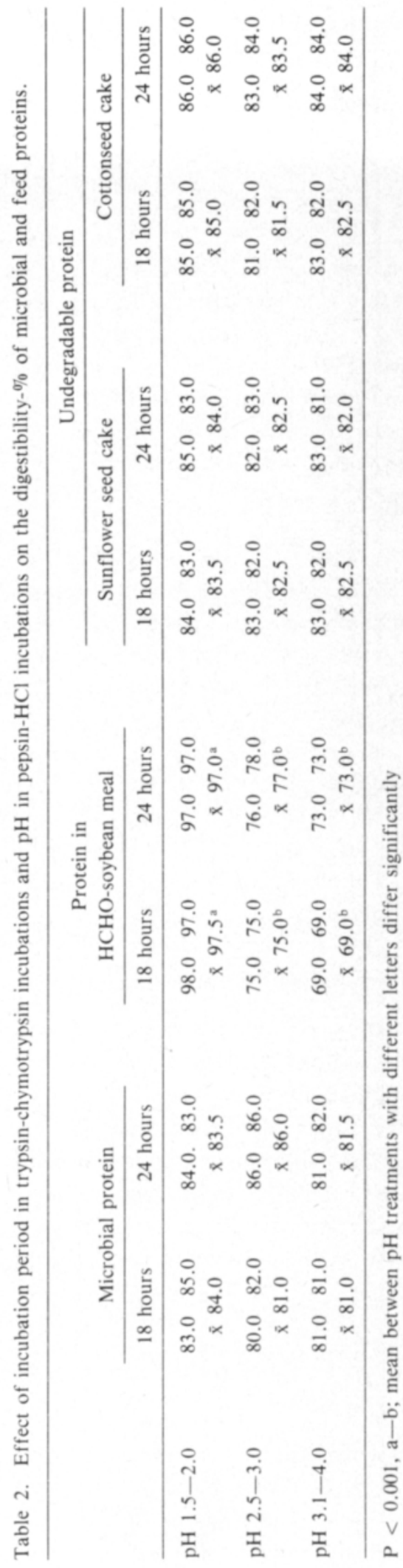


sum. McAllan (1981) reported an average value, $\mathrm{pH} 2.9$, for steers and the $\mathrm{pH}$ varied form 2.50 to 3.17 . Moreover, he also suggested that $\mathrm{pH}$ in the small intestine can vary being 5.69 at the beginning of the intestine and approaching $\mathrm{pH} 7.3$ at the terminal end of the small intestine.

In order to study the $\mathrm{pH}$ effect, the $\mathrm{pH}$ in pepsin- $\mathrm{HCl}$ incubations was adjusted to three different levels (Tables 2 and 3). However, any clear changes in the digestibility of undegraded feed proteins and microbial protein were not observed when the $\mathrm{pH}$ varied from 1.5 to 4.0. Ambrose and SNyder (1964) also found only a limited effect on protein digestibility caused by a change in the $\mathrm{pH}$ from 1.2 to 2.5 . The digestibility of the formaldehyde treated feed protein was significantly $(\mathrm{P}<0.001)$ decreased when a $\mathrm{pH}$ higher than $1.5-2.0$ was used. These results demonstrated the importance of acidic conditions for the release of formaldehyde-protein complex as suggested for instance by FERGUSON et al. (1967) although on the basis of their results as low a $\mathrm{pH}$ as in our study would not be necessary.

The effect of the $\mathrm{pH}$ on the incubations with trypsin-chymotrypsin was not studied. JoHNSON et al. (1983) reported that a $\mathrm{pH}$ higher than 6.9 could change the activity of some enzymes of the pancreatin. At least this was the case with $\alpha$-amylase. However, according to the paper of McAlLAN (1981) the effect of $\mathrm{pH}$ in vivo may not be significant in controlling the activity of trypsin and chymotrypsin.

When protein digestibilities in vitro are applied to in vivo a critical point might be the length of the incubation period, e.g. the retention time of the feed particles in the abomasum and in the small intestine of the ruminant. In pepsin- $\mathrm{HCl}$ incubations length of the incubation may not be important if the activity of pepsin is reasonably high (e.g. AOAC-standard). In that case Ambrose and SNYDER (1964) did not report clear differences in digestibilities evaluated after the periods of $2,4,6$, or 16 hours.

In the literature there is not very much information available about the retention time of feed particles in the abomasum and small intestine. In one of the publications ColuCCI et al. (1982) reported retention times from 11 to 17 hours for concentrate and roughage in the omasum, abomasum, and small intestine. According to these findings an incubation period of 24 hours in our study was too long. When the incubation period was shortened to 18 hours, which is still reasonable regarding the practical work, there were very small and non-significant changes in the digestibility values of microbial and feed proteins (Table 2).

The digestibilities of undegradable proteins in cotton seed cake and sunflower seed cake were, however, generally higher than reported in vivo by HVELPLUND (1983). It is

Table 3. Statistical parameters of the data in table 2 (analysis of variance, factorial experiment).

\begin{tabular}{lrcrc}
\hline $\begin{array}{l}\text { Source of } \\
\text { variation }\end{array}$ & $\begin{array}{r}\text { Sum of } \\
\text { squares }\end{array}$ & $\begin{array}{c}\text { Degrees of } \\
\text { freedom }\end{array}$ & $\begin{array}{c}\text { Mean } \\
\text { square }\end{array}$ & F-value \\
\hline Incubation & 0.0083 & 1 & 0.0083 & 11.1389 \\
$\mathrm{~S}$ (substrate) & 33.4167 & 3 & 18.7500 & $36.2168^{* * *}$ \\
$\mathrm{P}$ (period) & 18.7500 & 1 & 294.1458 & $20.6380^{* * *}$ \\
$\mathrm{pH}$ & 588.2917 & 2 & 167.6181 & 4.5625 \\
$\mathrm{~S} \times \mathrm{pH}$ & 1005.7083 & 6 & 3.2014 & \\
$\mathrm{P} \times \mathrm{pH}$ & 9.1250 & 2 & 8.1218 & \\
$\mathrm{~S} \times \mathrm{pH} \times \mathrm{P}$ & 19.2083 & 6 & 23 & \\
Error & 186.8017 & & & \\
\hline
\end{tabular}

$* * * \mathrm{P}<0.001$ 
possible that the in vitro conditions created optimum circumstances for the activity of enzymes and therefore higher digestibilities were obtained.

In conclusion, the in vitro technique is a reasonable method in evaluation of protein digestibility in the lower digestive tract of a ruminant when it is used in studies with microbial protein or nylon bags. However, the analysis has to be carefully made if $\mathrm{HCHO}$ treated feeds are studied.

It is clear that the described technique is relatively complicated and laborous, but it is more simple than the in vivo techniques generally available. However, direct comparisons between in vitro and in vivo determinations have to be made, before in vitro results can be applied to in vivo conditions.

\section{References}

Akeson, W. R. \& Stahman, M. A. 1964. A pepsin pancreatin digest index of protein quality evaluation. J. Nutr. 83: 257-261.

Ambrose, M. E. \& Snyder, D. G. 1964. Pepsin digestibility: As an index of quality in fish meal: Part I. Some studies in the USA. Fishing News International 3 (3): 210, 212-213.

ANON 1970. Official methods of analysis of the Association of Official Analytical Chemists. 11th ed. p. 127-128. Washington.

Bergen, W. G., Purser, D. B. \& Cline, J. H. 1967. Enzymatic determination of the protein quality of individual rumen bacteria. J. Nutr. 92: 357-364.

Buchmann, N. B. 1979. In vitro digestibility of protein from barley and other cereals. J. Sci. Fd. Agric. 30: 583-589.

Colucci, P. E., Chase, L. E. \& Van Soest, P. J. 1982. Feed intake, apparent diet digestibility, and rate of particulate passage in dairy cattle. J. Dairy Sci. 65: 1445-1456.

Engelhardt, W., von \& Hauffe, R. 1975. Role of the omasum in absorbtion and secretion of water and electrolytes in sheep and goats. Digestion and metabolism in the ruminant, ed. McDonald, I. W. and Warner, A. C. I. p. 222. The University of New England publ. unit.

Ferguson, K. A., Hemsiey, J. A. \& Reis, P. J. 1967. The effect of protecting dietary protein from microbial degradation in the rumen. Aust. J. agric. Sci. 30: 215-217.

Hagemeister, H., Lopping, E. \& Kaufmann, W. 1980. Microbial protein synthesis and digestion in the highyielding dairy cow. Resent advances in animal nutrition -1980 , ed. Haresign, W. p. 67-84. Butterworths.

Hsu, H. W., Vavak, D. L., Satterlee, L. D. \& Miller, G. A. 1977. A multienzyme technique for estimating protein digestibility. J. Food Sci. 42: 1269-1273.

Hvelplund, T. 1983. Digestibility of rumen microbial protein and undegraded dietary protein in the small intestine of sheep. Protein metabolism and nutrition II. p. 283-286. INRA.

Johnson, D. D., Mitchell, G. E., Jr., Tucker, R. E. \& Muntifiering, R. B. 1983. Ovine pancreatic alphaamylase digestion of purified, feed, or abomasal starch as affected by pH. J. Anim. Sci. 57, suppl. 1. Abstract 13, p. 6.

KORTE, H. 1979. Vergleichende Untersuchungen zur Proteinverdaulichkeit mit Hilfe der Pepsin- $\mathrm{HCl}$ Methods. Diplomarbeit, Kiel, 47 p.

Kowalczyk, J., Pastuzewska, B. \& Otwinowska, A. 1977. Biological value of protein for rats and digestibility of nutrients of a diet containing formaldehyde-treated rapeseed oilmeal. Rocz. Nauk Rolnicz. 98 B: $91-97$.

-, Jaczewska, A. \& Drozdz, A. 1978 a. Decomposition of protein in formaldehyde treated or untreated feeds by the contents of the rumen or abomasum in vitro. Rocz. Nauk Rolnicz. 98 B: 17-24.

-, BARTIK, M. \& JACZEWSKA, A. 1978 b. A note on enzymic digestion of protein treated with formaldehyde. Rocz. Nauk Rolnicz. 99 B: 123-127.

McAllan, A. B. 1981. Changes in the composition of digesta during passage through the small intestines of steers. Br. J. Nutr. 46: 431-440.

Mozersky, S. M. \& Panettieri, R. A. 1983. Is pH drop a valid measure of extent of protein hydrolysis. J. Agric. Food Chem. 31: 1313-1316.

ROJAHN, J. \& WAGNER, J. 1961. In vitro - Verdaulichkeitsversuche des Rohproteins und einiger Aminosäuren der Nackt- und Spelzgerste. Arch. für Tierern. 11: $145-156$.

Storm, E. \& Ørskov, E. R. 1982. Biological value and digestibility of rumen microbial protein in lamb small intestine. Proc. Nutr. Soc. 41: 78 A.

-, Ørskov, E. R. \& Smart, R. 1983. The nutritive value of rumen micro-organisms in ruminant. 2. The apparent digestibility and net utilization of microbial $\mathrm{N}$ for growing lambs. Br. J. Nutr. 50: 471-478.

Tas, M. V., Axford, R. F. E. \& Evans, R. A. 1977. 
The digestibility of rumen microbial protein in the small intestines of sheep. Proc. Nutr. Soc. 36: 79 A

Van Bruchem, J. \& Van't Klooster, A. Th. 1980. Effect of protein on abomasal secretion of acid in sheep. Br. J. Nutr. 44: 307-312.

SELOSTUS

\section{Proteiinin sulavuuden määrittäminen märehtijän juoksutusmahassa ja ohutsuolessa in vitro}

\author{
Jouko Setälä, Hanna Väätäinen ${ }^{1}$ ja \\ Terttu Ettala \\ Valion tutkimus- ja tuotekehittelyosasto, PL 176, \\ 00181 Helsinki
}

Tutkimuksessa selvitettiin pötsin sisällöstă sentrifugoimalla erotetun mikrobiproteiinin sekă nailonpussimenetelmällă tuotetun pötsissă hajoamattoman rehuproteiinin sulavuutta in vitro -menetelmällä. Mikrobiproteiini eristettiin lampailta, jotka olivat joko heinätai heină-säilörehu -ruokinnalla. Tutkittavat rehut olivat auringonkukkakakku ja puuvillasiemenkakku. Lisäksi tarkasteltiin formaldehydi-käsittelyn $(0,5 \%$-käsittely) vaikutusta soijarouheen valkuaisen sulavuuteen.

In vitro -menetelmässã tutkittava substraatti inkuboitiin pepsiini-HCl- ja trypsiini-kymotrypsiini -liuoksessa.
Wallace, R. J. 1983. Digestion of rumen bacteria in vitro. Br. J. Nutr. 49: 101-108.

Ms received 16 May, 1984
Mikrobiproteiinin keskimääräinen sulavuus oli 80,7 \% ja aurinkokukkakakun sekä puuvillasiemenkakun pötsissä hajoamattoman proteiinin sulavuus vastaavasti $83,7 \%$ ja $82,7 \%$.

Pepsiini- $\mathrm{HCl}$-inkubaatiossa kãytetty $\mathrm{pH}$ vaikutti merkitsevästi $(\mathrm{P}<0.001)$ formaldehydi-käsitellyn soijarouheen valkuaisen sulavuuteen. Sulavuudet $\mathrm{pH}$-alueilla $1.5-2.0,2.5-3.0$ ja $3.1-4.0$ olivat vastaavasti $97,2 \%, 76,0 \%$ ja $71,0 \%$.

1 MTTK, kotieläinhoito-osasto, 31600 Jokioinen 